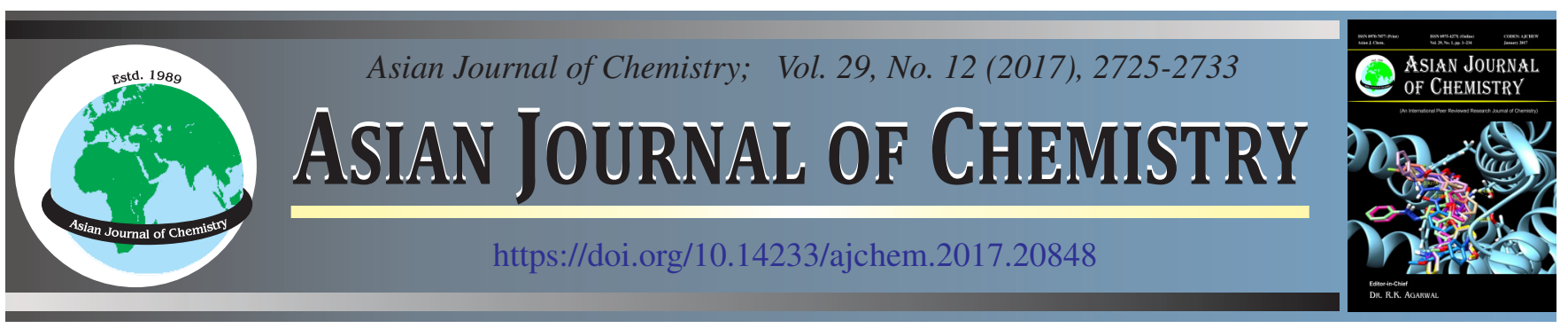

\title{
Cloud Point Extraction and Determination of Trace Iron(III) in Urine Samples by Spectrophotometry and Flame Atomic Absorption Spectrometry
}

\author{
Ahmed Fadhil Khudhair ${ }^{*}$ and Mouyed Khudhair Hassan
}

Department of Chemistry, College of Science, University of Karbala, Karbala, Iraq

*Corresponding author: E-mail: aliahmed79f@yahoo.com, ahmedfadhilkhudhair@gmail.com

Received: 8 June 2017;

Accepted: 17 September 2017;

Published online: 30 October 2017;

AJC-18623

\begin{abstract}
Cloud point technique used effectively for extraction and pre-concentration of iron(III) in the urine samples of occupational workers prior measured by using flame atomic absorption spectrometry and UV-visible spectrophotometer. The metal responds with benzidine as reagent in a non-ionic surfactant Triton X-114 medium. The main factors affecting cloud point extraction efficiencies, such as pH of sample solution, concentration of benzidine reagent, type of surfactant, concentration of Triton X-114, effect of salt out, influence of interferences and impact of equilibration temperature and time were studied. The calibration curve was linear in the range of $0.25-3.0 \mu \mathrm{g}$ $\mathrm{mL}^{-1}$ with $\mathrm{r}^{2}=0.9655$ for UV-visible spectrophotometer at $\lambda_{\max } 425 \mathrm{~nm}$. The limit of detection was $0.25 \mu \mathrm{g} \mathrm{mL} \mathrm{m}^{-1}$. The relative standard deviation for six replicates was $3.071 \%$.
\end{abstract}

Keywords: Cloud point extraction, Triton X-114, UV-visible spectrophotometer, Iron(III), Benzidine, Urine samples.

\section{INTRODUCTION}

The increase in the concentration of trace components relative to the total component concentration can be achieved with pre-concentration techniques [1]. There are multiple methods of pre-concentration for metals, like solid phase extraction (SPE), cloud point extraction (CPE), electrochemical deposition, co-precipitation and precipitation, liquid-liquid extraction (LLE) and ion-exchange [2-5]. In this study, emphasis was placed on the use of cloud point extraction technique for several reasons viz., high recovery efficiency, high concentration coefficient [6], green chemistry, less consuming reagent, less production of chemical residues, surfactant used is safe, non-volatile and non-toxic simplicity [7,8]. A pre-concentration method including the process of cloud point extraction is depended on the use of non-ionic varieties of surfactants in aqueous solutions and thus the formation of micelles and by heating these solutions to a certain temperature will become cloudy or turbid this temperature is known as the cloud point temperature [9]. Cloud point extraction is used with coupling with different techniques for estimating various elements in different samples such as, cloud point extraction to pre-concentration and analysis of strontium (II) ion by turbidimetric method using Schiff base derivative [10].

The increases in the concentration of iron in the body have negative effects including endocrine problems and diseases of the liver, lung and other diseases [11-14]. The previous literature review conducted to determine the iron element in various samples by using cloud point extraction method that is coupled with different techniques such as: flame atomic absorption spectrometry (FAAS) $[12,15,16]$, UV-visible spectrophotometer $[17,18]$, inductively coupled plasma mass spectrometry [19], graphite furnace atomic absorption spectrometry [20] and capillary electrophoresis [21]. The urine has a pH of 5.5- 7.0 and a range of 6.2 [22], while the concentration of iron element in the urine is estimated to be about the median and range concentration of iron in urine was $4.9 \mathrm{ng} \mathrm{mL}^{-1}$ and $<2.1-16.4 \mathrm{ng} \mathrm{mL} \mathrm{mL}^{-1}$ [23-26]. The aim of this study was to develop simple spectrometric method for the determination of Fe(III), using benzidine as a complexing agent and cloud point extraction. The proposed method is successfully applied for the determination iron(III) in urine of occupational worker samples.

\section{EXPERIMENTAL}

A pH meter WTW (model 720) with a combined glass electrode was used for $\mathrm{pH}$ measurements. A Hettich centrifuge (model EBA-20, Germany) with $10 \mathrm{~mL}$ calibrated centrifuge tubes was used for phase separation at $3600 \mathrm{rpm}$ for $5 \mathrm{~min}$. A Lab Line Super mixer (model 129) Hitech Trader, USA was used to mix the solutions. Shimadzu double beam UV-VIS Spectrophotometer, UV-1800, Japan is used to measure all 
absorption spectra. The metals ions have been determined by using flame atomic absorption spectrophotometer (FAAS) (Buck scientific model 210 VGP, USA) with deuterium background correction equipped with $10 \mathrm{~cm}$ of air/acetylene flame burner head and hollow-cathode lamp that can be changed with metal ion.

Most of the chemicals have been prepared by using analytical grade chemicals and deionized water. Benzidine reagent $(1 \% \mathrm{w} / \mathrm{v})$ was prepared by dissolving $1 \mathrm{~g}$ of benzidine in 1-2 $\mathrm{mL}$ dimethyl sulfoxide and then add absolute ethanol to 100 $\mathrm{mL}$ in a volumetric flask. Solutions of non-ionic surfactant Triton X-114 have prepared at $20 \%$ (v/v) concentration by diluting $20 \mathrm{~mL}$ of Triton X-114 to $100 \mathrm{~mL}$ (hot deionized water) in a volumetric flask. A stock solution of $1000 \mathrm{mg} / \mathrm{L}$ of $\mathrm{Fe}(\mathrm{III})$ was prepared by dissolving $0.2920 \mathrm{~g}$ of $\mathrm{FeCl}_{3}$ in 100 $\mathrm{mL}$ deionized water.

Sample collection: A 44 urine samples were collected from occupational workers workers in oil refineries and terminals engaged in dyeing, welding, plumbing, etc. The urine samples were collected in a new polyethylene bottles $(120 \mathrm{~mL})$ and stored at $0-5^{\circ} \mathrm{C}$ [27].

Urine sample digestion: In a $100 \mathrm{~mL}$ beaker, $25 \mathrm{~mL}$ of urine sample accurately measured, was treated with a mixture of $5 \mathrm{~mL} \mathrm{H}_{2} \mathrm{O}_{2}$ and $2.5 \mathrm{~mL}$ of conc. $\mathrm{HNO}_{3}$, and was placed on a hot plate. Then the samples are heated until the sample become complete dry. Thereafter, a dry residuum with a dark colour is added to $2.5 \mathrm{~mL}$ of conc. $\mathrm{HNO}_{3}$ and heated again to the point of drought. This step is repeated several times until a white ashes were obtained. The white ashes were dissolved in the final step by using $2.5 \mathrm{~mL}$ of $3 \mathrm{M}$ of $\mathrm{HCl}[28,29]$.

Cloud point extraction: The precocentration and extraction procedure for iron(III) by using cloud point extraction method aliquots of $10 \mathrm{~mL}$ of $\mathrm{Fe}(\mathrm{III})$ solution containing $2 \mu \mathrm{g} \mathrm{mL} \mathrm{mL}^{-1}$ and $0.5 \mathrm{~mL}$ of $1 \%(\mathrm{w} / \mathrm{v})$ of benzidine reagent was mixed. The green colour solution product formed has $\lambda_{\max } 425$ $\mathrm{nm}$ depending on the absorption spectra of UV-visible spectrometry for $\mathrm{Fe}(\mathrm{III})$-benzidine complex. After adjusted the $\mathrm{pH}$ at 4.2 by using $0.1 \mathrm{M}$ of $\mathrm{HCl}$ and $0.1 \mathrm{M}$ of $\mathrm{NaOH}$, added $0.1 \mathrm{~mL}$ of $20 \%(\mathrm{v} / \mathrm{v})$ Triton X-114. Then the mixture placed on the super mixer to mix and heated on a water bath at $70{ }^{\circ} \mathrm{C}$ for 10 min. This step follows the separation of the solution into two layers via the centrifuge at $3600 \mathrm{rpm}$ for $5 \mathrm{~min}$. After that the phases are cooled using an ice bath at $0-5{ }^{\circ} \mathrm{C}$ to increase the viscosity so that surfactant-rich phase separated easily by converting tube. The remaining micellar phase containing $\mathrm{Fe}$ (III)-benzidine complex was dissolved in $0.75 \mathrm{~mL}$ of absolute ethanol and transferred into $1 \mathrm{~cm}$ quartz cell $(1 \mathrm{~mL})$. Then measured the absorbance of solution against a blank solution prepared in the same way. The proposed reaction mechanism for Fe(III)benzidine complex formation is shown in Fig. 1.
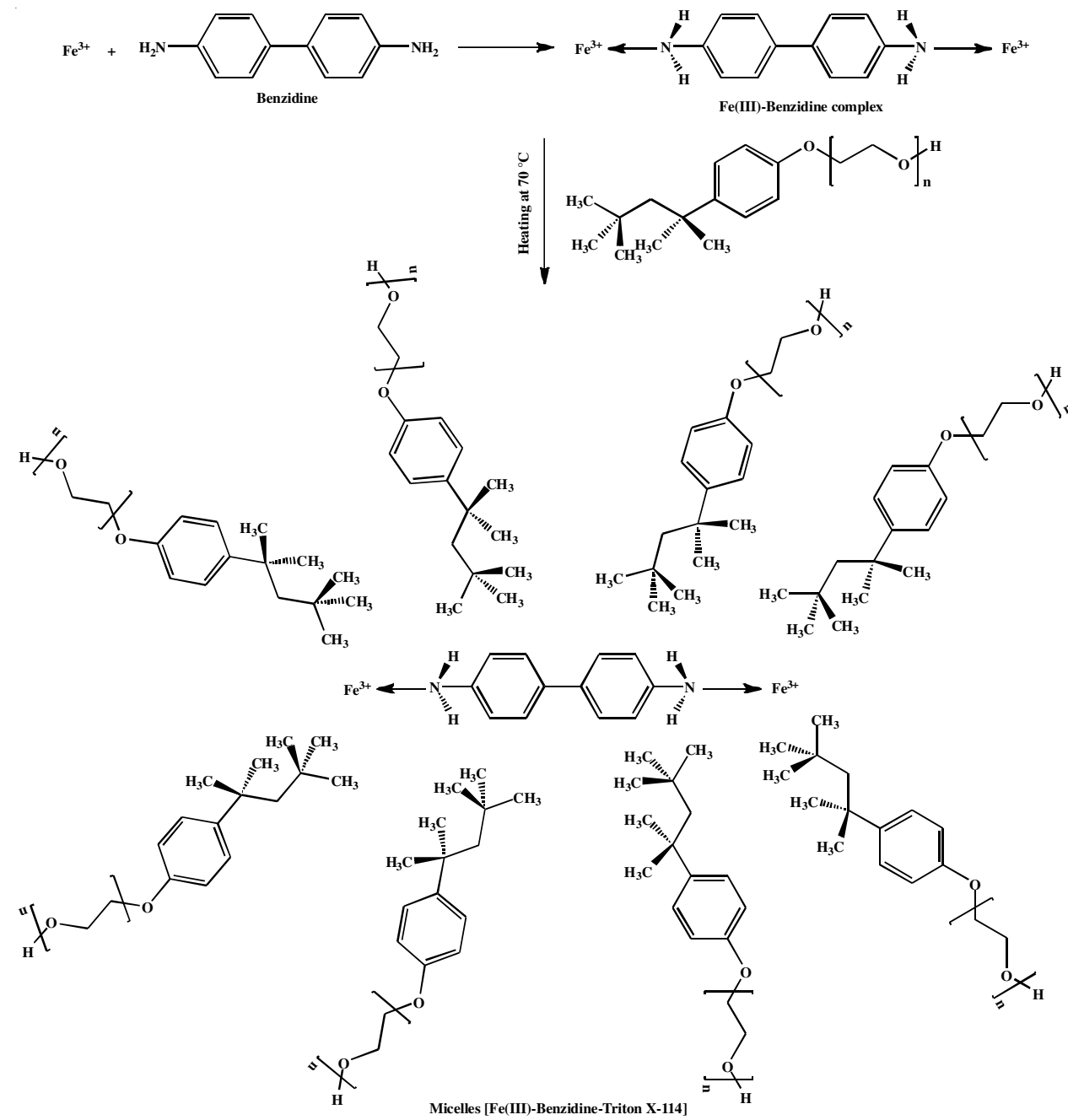

Fig. 1. Proposed reaction mechanism for Fe(III)-benzidine complex formation 
Absorption spectra for Fe(III)-benzidine complex: The absorbance spectra for benzidine, iron(III) solution and Fe(III)benzidine complex in surfactant rich phase are domenstrated Fig. 2. The absorbance spectra of benzidine reagent shows $\lambda_{\max } 288 \mathrm{~nm}$, iron(III) solution has $\lambda_{\max } 320 \mathrm{~nm}$, while Fe(III)benzidine complex has $425 \mathrm{~nm}$.

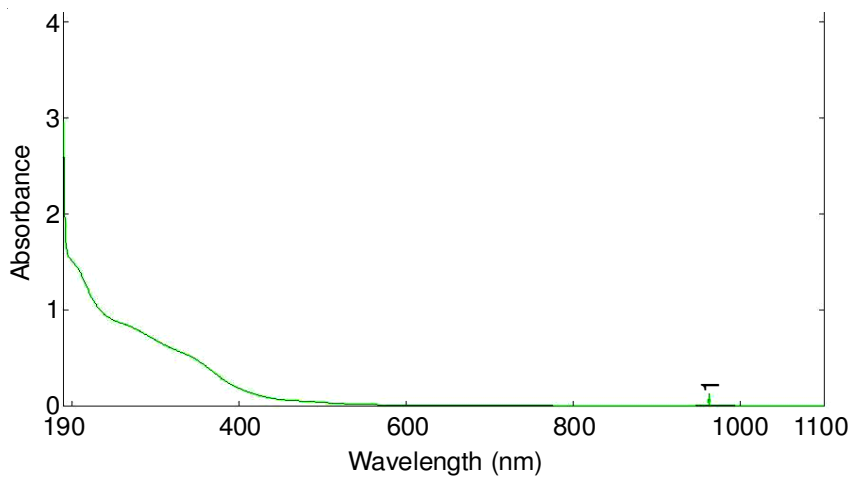

Fig. 2A. Absorption spectra of iron(III) solution

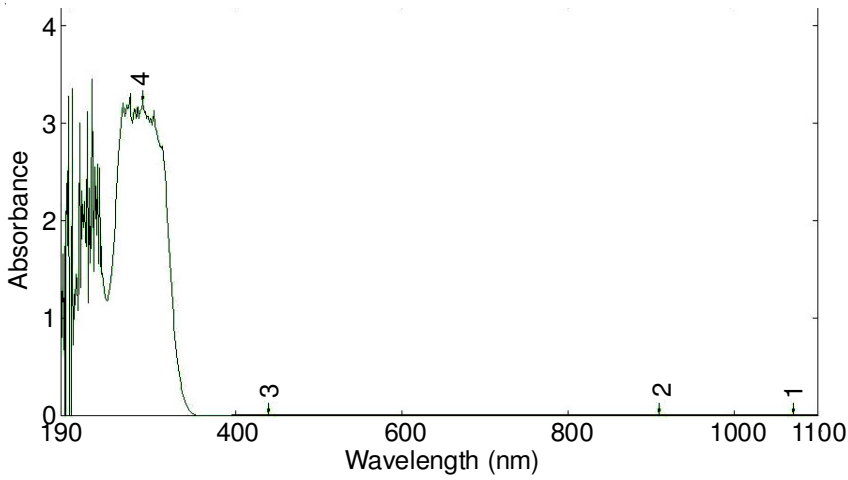

Fig. 2B. Absorption spectra of benzidine reagent solution

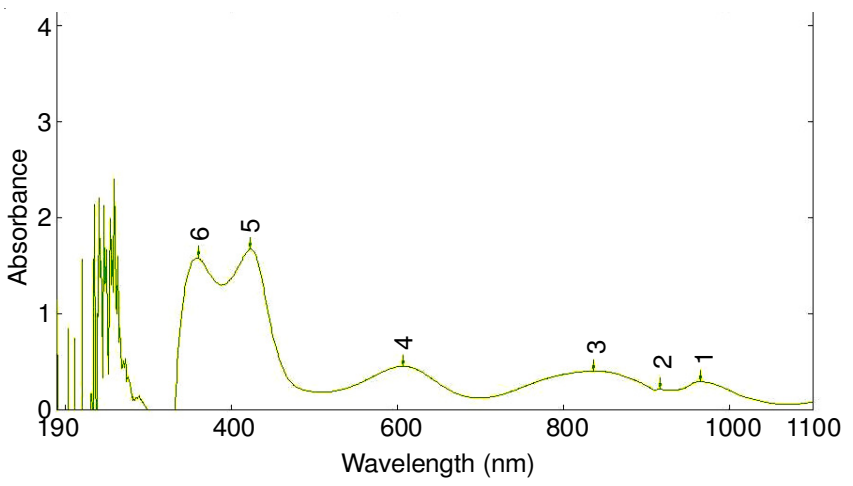

Fig. 2C. Absorption spectra of iron(III)-benzidine complex

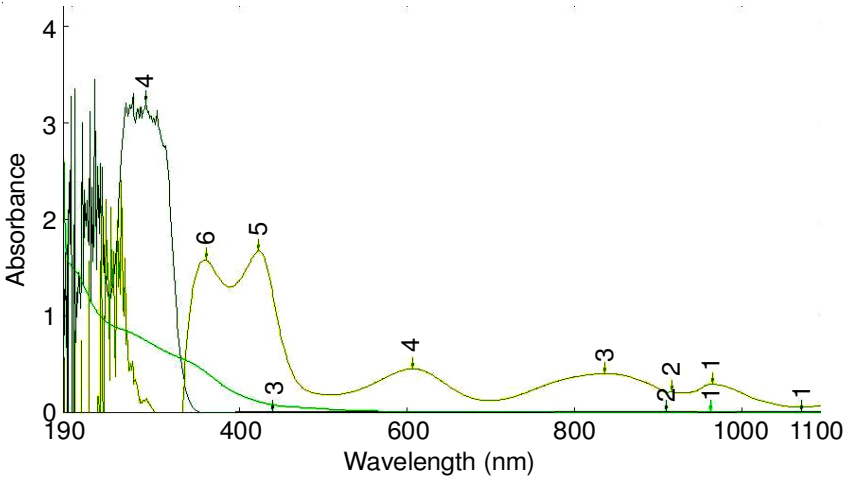

Fig. 2D. Over lapping for Fe(III)-benzidine complex

\section{RESULTS AND DISCUSSION}

The optimal conditions for high efficiency of cloud extraction were studied and stabilized. The most important conditions are order addition, $\mathrm{pH}$, concentration of reagent, types of surfactant, concentration of surfactant, equilibrium temperature, time of incubation, salt out effect and interfering ions.

Order addition effect: The most important factors that have been studied are order additions where it changed the order of $\left(2 \mu \mathrm{g} \mathrm{mL}^{-1}, 10 \mathrm{~mL}\right)$ of $\mathrm{Fe}(\mathrm{III})$ and $(1 \% \mathrm{w} / \mathrm{v}, 0.5 \mathrm{~mL})$ of benzidine reagent (Table-1). The greatest absorbance value was chosen accordingly.

\begin{tabular}{cccc} 
TABLE-1 & \multicolumn{2}{c}{ EFFECT OF ORDER ADDITION } \\
\hline $\begin{array}{c}\text { Type of } \\
\text { complex }\end{array}$ & Order addition & $\begin{array}{c}\text { Absorbance of } \\
\text { an aqueous } \\
\text { layer (Aq) }\end{array}$ & $\begin{array}{c}\text { Absorbance of } \\
\text { a rich phase } \\
\text { surfactant (As) }\end{array}$ \\
\hline $\begin{array}{cccc}\text { Fe(III) } \\
\text { complex }\end{array}$ & $\mathrm{M}+\mathrm{R}+\mathrm{T}$ & 0.000 & 0.295 \\
\hline
\end{tabular}

Effect of pH: $\mathrm{pH}$ is one of the most important factors that directly affect the formation of the iron complex by using cloud point extraction. The test was applied using the range of $\mathrm{pH} 2.7-10.4$. These values were adjusted using by $0.1 \mathrm{M} \mathrm{NaOH}$ and $0.1 \mathrm{M} \mathrm{HCl}$ solution. The absorbance increased, when the $\mathrm{pH}$ value equal 4.2, the complexation reaction at $\mathrm{pH}$ values lower than 4.2 is incomplete probably due to the protonation of benzidine (Fig. 3). On the other hand at $\mathrm{pH}$ value higher than 4.2 is due to hydrolysis of Fe(III). The effects of different types of acids ( $0.1 \mathrm{M}$ ) are shown (Fig. 4). The effect of hydrochloric acid on $\mathrm{Fe}$ (III)-benzidine complex formation is stronger as compared to other acids, where it gave the highest absorbance. It is also found that volume $0.75 \mathrm{~mL}$ of $0.1 \mathrm{M}$ of $\mathrm{HCl}$ gave best absorbance (Table-2).

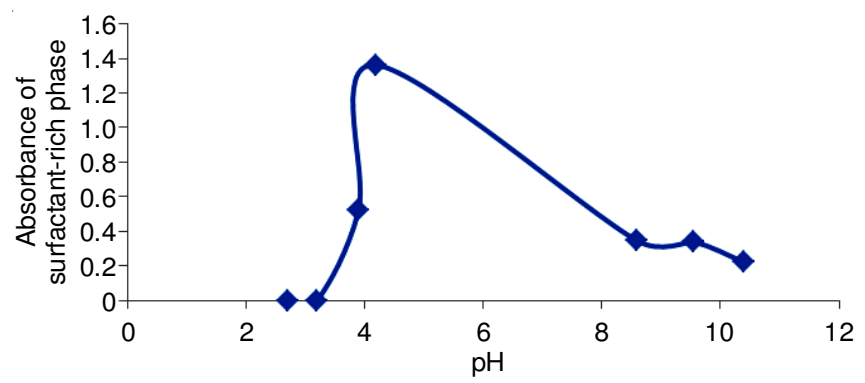

Fig. 3. Effect of $\mathrm{pH}$

TABLE-2

EFFECT CONCENTRATION OF HCl

\begin{tabular}{cccc}
\hline Volume of \\
\cline { 2 - 4 } $\mathrm{HCl}(\mathrm{mL})$ & $\begin{array}{c}\text { Original } \\
\text { solution }\left(\mathrm{A}_{\mathrm{o}}\right)\end{array}$ & $\begin{array}{c}\text { Aqueous layer } \\
(\mathrm{Aq})\end{array}$ & $\begin{array}{c}\text { Rich phase } \\
\text { surfactant }(\mathrm{As})\end{array}$ \\
\hline 1.00 & 0.000 & 0.000 & 0.899 \\
0.75 & 0.000 & 0.000 & 1.060 \\
0.50 & 0.000 & 0.000 & 0.454 \\
0.25 & 0.000 & 0.000 & 0.084 \\
0.10 & 0.000 & 0.000 & 0.007 \\
0.05 & 0.000 & 0.000 & 0.010 \\
\hline
\end{tabular}




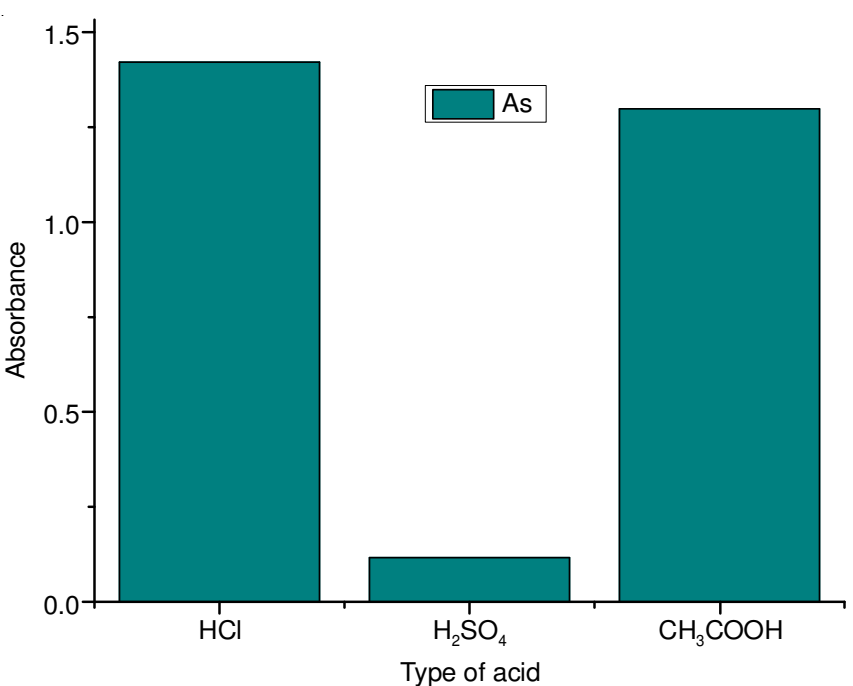

Fig. 4. Effect of different acids

Effect of reagent concentration: The concentration effect of chelating agent i.e., benzidine on absorbance value was studied by using various volumes from 0.05 to $1.00 \mathrm{~mL}$ of $1 \% \mathrm{w} / \mathrm{v}$ of benzidine while keeping other factors constant. The results (Fig. 5) show that the absorbance value increased with increasing amount of added reagent benzidine. The best result was relied upon when the amount of reagent is $0.5 \mathrm{~mL}$.

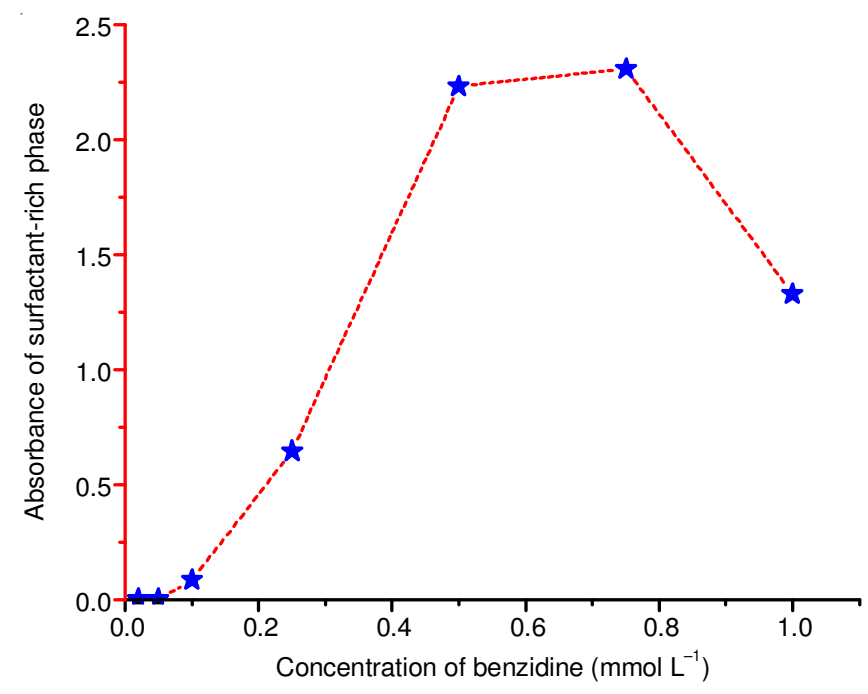

Fig. 5. Effect of concentration of reagent

Influence of type and concentration of surfactant: The efficiency of cloud point extraction dependent on the type of surfactant used. Fig. 6 shows the effect type of surfactants (Triton X-100, sodium dodecyl sulfate (SDS) and Triton X114) and its concentration on absorbance of Fe(III)-benzidine complex. Fig. 7 shows the absorbance of the complex increased by increasing the volume of $20 \%(\mathrm{v} / \mathrm{v})$ Triton X-114.

Effect of equilibrium temperature and time: Fig. 8 shows the highest absorbance signal at $70{ }^{\circ} \mathrm{C}$. In order to achieve easy phase separation and efficient pre-concentration in cloud point extraction processes, it was desirable to employ the shortest incubation time. The effect of incubation time was investigated in the ranges $1-25 \mathrm{~min}$. The results demonstrate that in the incubation time of 5 min was chosen for further

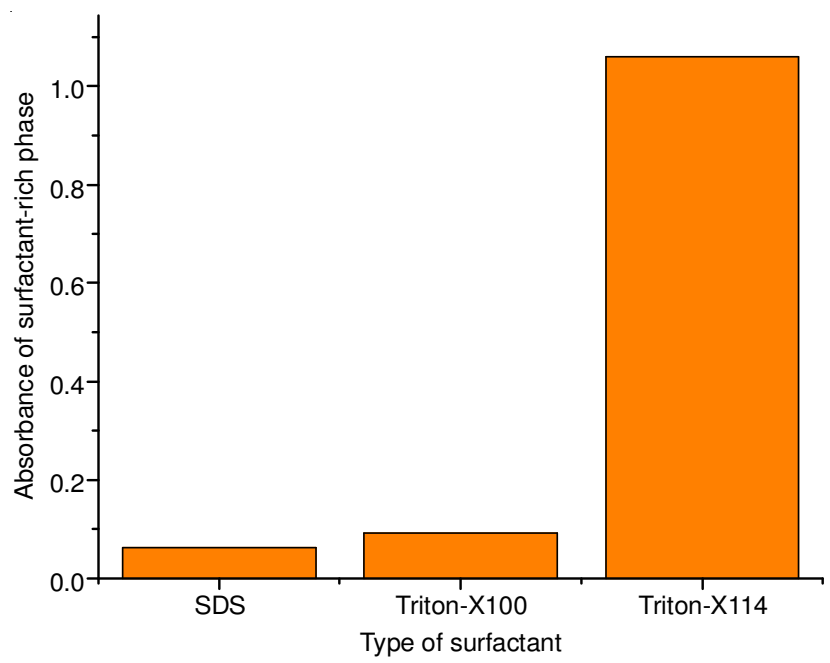

Fig. 6. Effect of type of surfactant

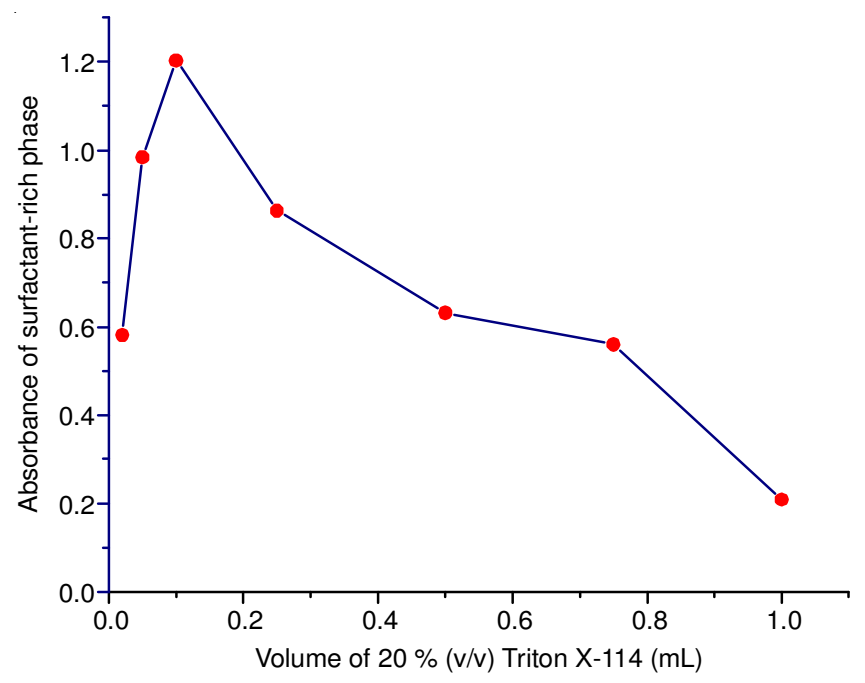

Fig. 7. Effect of concentration of Triton X-114

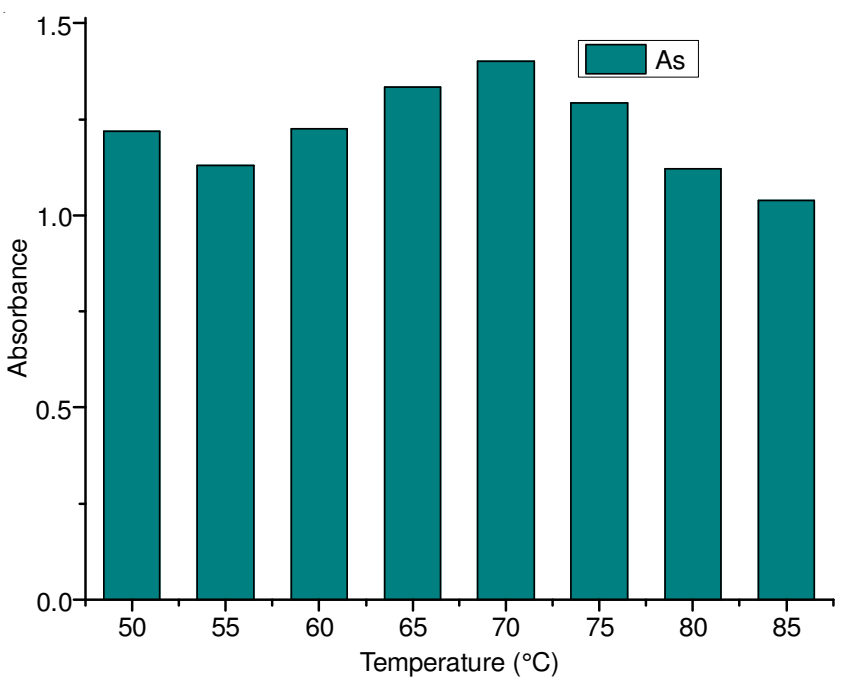

Fig. 8. Effect of temperature

experiments. Fig. 9 showed the effect of incubation time on the complex formation.

Effect of salts: The effect of salts on cloud point extraction were studied by added $0.5 \mathrm{~mL}$ of $15 \% \mathrm{w} / \mathrm{v}$ of $\mathrm{NaCl}, \mathrm{KCl}$, $\mathrm{Na}_{2} \mathrm{CO}_{3}$ and $\mathrm{Na}_{2} \mathrm{SO}_{4}$ to solution of $\mathrm{Fe}(\mathrm{III})$. The results demons- 


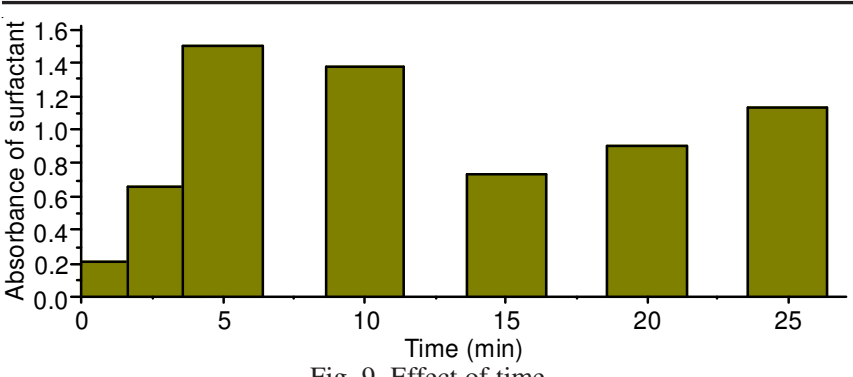

Fig. 9. Effect of time

trate that the presence of some salts lead to increase the absorbance value which is attributed due to the increase in cloud point extraction efficiency since these salts will pull water molecules and destroy the hydration shell of iron ion which leads to increase the bonding between the reagent benzidine and iron. Table- 3 shows the effect of salt out on complex.

\begin{tabular}{cccc}
\multicolumn{4}{c}{ TABLE-3 } \\
EFFECT OF SALT \\
\hline $\begin{array}{c}\text { Salts } 0.5 \mathrm{~mL} \text { of } \\
15 \%(\mathrm{w} / \mathrm{v})\end{array}$ & $\begin{array}{c}\text { Absorbance of } \\
\text { a rich phase }\end{array}$ & Recovery $(\%)$ & $\mathrm{E}_{\mathrm{re}}(\%)$ \\
\hline $\mathrm{NaCl}$ & 0.442 & 39.21917 & 60.780 \\
$\mathrm{KCl}$ & 0.401 & 35.58119 & 64.418 \\
$\mathrm{Na}_{2} \mathrm{CO}_{3}$ & 0.404 & 35.84738 & 64.152 \\
$\mathrm{Na}_{2} \mathrm{SO}_{4}$ & 2.103 & 186.6016 & 86.601 \\
\hline
\end{tabular}

Effect of interference ions: The effects of foreign ions on the extraction of $2 \mu \mathrm{g} \mathrm{mL^{-1 }}$ of $\mathrm{Fe}$ (III) were studied, cations that may react with benzidine or species may react with analytes and decrease the extraction efficiency to perform this study, $100 \mu \mathrm{g} \mathrm{mL}^{-1}$ of interfering ions were added to a solution of $2 \mu \mathrm{g} \mathrm{mL} \mathrm{m}^{-1}$ of Fe (III) and were subjected to the complete procedure. The results demonstrate that the presence of large amounts of species commonly present in water samples have significant effect on the cloud point extraction efficiency. Table4 shows the effect of interferences on the complex.

\begin{tabular}{|c|c|c|c|}
\hline \multicolumn{4}{|c|}{$\begin{array}{c}\text { TABLE-4 } \\
\text { EFFECT OF INTERFERENCES IONS }\end{array}$} \\
\hline $\begin{array}{l}\text { Interfering } \\
\quad \text { ion }\end{array}$ & Added as & $\begin{array}{l}\text { Concentration of } \\
\text { Interfering ion } \\
\text { ppm/Conc. of } \\
\mathrm{Cu}(\mathrm{II}) \text { ppm ratio }\end{array}$ & Absorbance \\
\hline $\mathrm{Co}$ (II) & $\mathrm{Co}\left(\mathrm{NO}_{3}\right)_{2}$ & 50 & 1.921 \\
\hline $\mathrm{Ni}(\mathrm{II})$ & $\mathrm{Ni}\left(\mathrm{NO}_{3}\right)_{2}$ & 50 & 1.642 \\
\hline $\mathrm{Cu}(\mathrm{II})$ & $\mathrm{Cu}\left(\mathrm{NO}_{3}\right)_{2} \cdot 3 \mathrm{H}_{2} \mathrm{O}$ & 50 & 1.803 \\
\hline $\mathrm{Cr}(\mathrm{III})$ & $\mathrm{Cr}\left(\mathrm{NO}_{3}\right)_{3}$ & 50 & 0.972 \\
\hline $\mathrm{Al}(\mathrm{III})$ & $\mathrm{Al}\left(\mathrm{NO}_{3}\right)_{3} \cdot 9 \mathrm{H}_{2} \mathrm{O}$ & 50 & 0.721 \\
\hline $\mathrm{Pb}(\mathrm{II})$ & $\mathrm{Pb}\left(\mathrm{NO}_{3}\right)_{2}$ & 50 & 1.721 \\
\hline $\mathrm{Zn}(\mathrm{II})$ & $\mathrm{ZnCl}_{2}$ & 50 & 1.812 \\
\hline
\end{tabular}

Stoichiometry of the complex: The stoichiometry of the complex determined by using two methods:

Job's method: In Job method, solution of reagent benzidine and iron(III) ion $1 \times 10^{-3} \mathrm{M}$ were prepared and mixed in continuous variation then diluted with $10 \mathrm{~mL}$ of deionized water after that measured the absorbance of solution by UV-visible spectrophotometer at $425 \mathrm{~nm}$. The stoichiometry of the complex determined Job's method was found to be 0.7-0.3. Fig. 10 showed the Job's plot of absorbance at $425 \mathrm{~nm}$ versus mole fraction of $\mathrm{Fe}(\mathrm{III})$ ion.

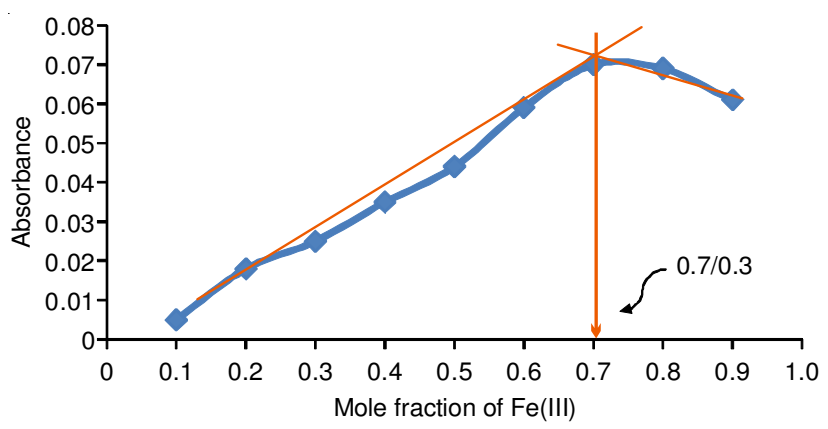

Fig. 10. Job method

Mole ratio method: In the mole ratio method, fixed the volume of $\mathrm{Fe}^{3+}$ ion $\left(1 \times 10^{-3} \mathrm{M}\right)$ and change volume of reagent benzidine $\left(1 \times 10^{-3} \mathrm{M}\right)$ or vice-versa, then diluted with $10 \mathrm{~mL}$ of deionized water and finally measured the absorbance of the solution by UV-visible spectrophotometer at $425 \mathrm{~nm}$. The stoichiometry of the complex determined by mole ratio method was found to be 2.33:1. Fig. 11 showed the mole ratio plot of benzidine-Fe(III) complex.

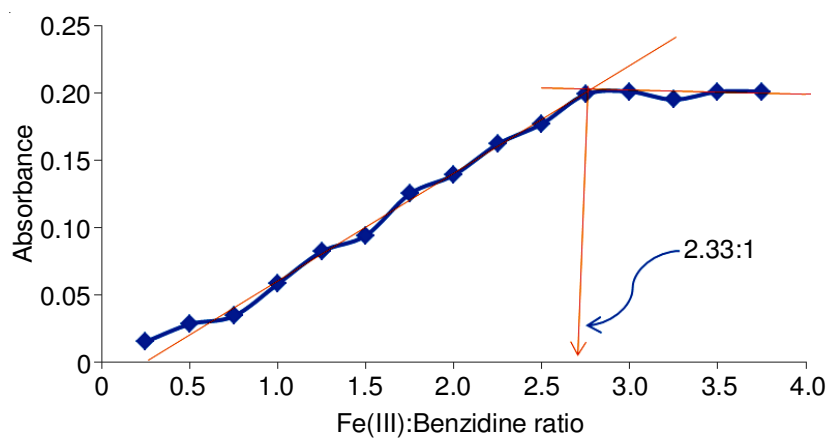

Fig. 11. Mole ratio

Calibration curve of $\mathrm{Fe}$ (III) by UV-visible with cloud point extraction: Calibration graphs were established by plotting absorbance versus concentration of $\mathrm{Fe}^{3+}$ ion. A series $0.1-7 \mu \mathrm{g} \mathrm{mL}^{-1} \mathrm{Fe}^{3+}$ ion were prepared. Table-5 and Fig. 12 showed the range of concentration of $\mathrm{Fe}(\mathrm{III})$, results of absorbance for linear regression analysis using cloud point extraction and calibration plot for Fe(III).

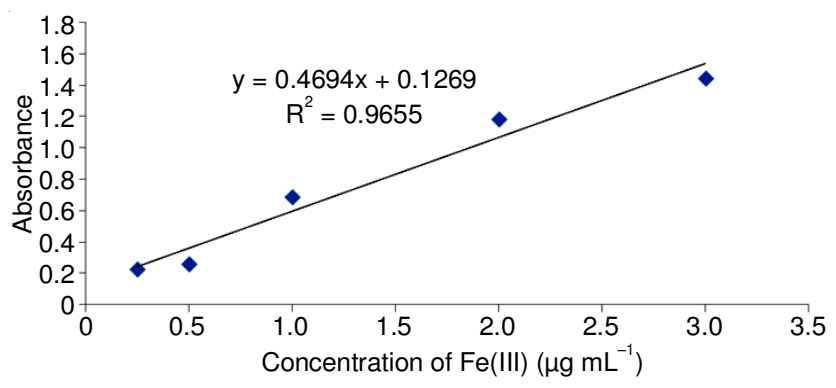

Fig. 12. Calibration graph for Fe(III) by UV-visible spectrophotometry

\section{Precision and accuracy}

Repeatability: This test is applied to the concentrations (0.5 and 2.0) $\mu \mathrm{g} \mathrm{mL}^{-1}$ of Fe(III). The values of relative standard deviation (RSD \%) for $\mathrm{Fe}^{3+}$ ion is tabulated in Table-6. The percentage relative standard deviation less than $5 \%$ can be achieved using this method. 


\begin{tabular}{|c|c|c|c|c|c|}
\hline \multicolumn{6}{|c|}{$\begin{array}{c}\text { TABLE-5 } \\
\text { RESULTS OF CALIBRATION GRAPH OF Fe(III) BY UV-VIS-CPE METHOD }\end{array}$} \\
\hline $\begin{array}{l}\text { Concentration of } \\
\mathrm{Fe}(\mathrm{III})\left(\mu \mathrm{g} \mathrm{mL} \mathrm{L}^{-1}\right)\end{array}$ & Absorbance $\left(\mathrm{y}_{\mathrm{i}}\right)$ & Mean $\bar{y}$ & $\begin{array}{l}\text { Standard deviation } \\
\qquad \sigma_{\mathrm{n}-1}\end{array}$ & RSD (\%) & $\begin{array}{l}\text { Confidence interval of mean } \\
\qquad \bar{y} \pm t_{0.05 / 2} \frac{\sigma_{\mathrm{n}-1}}{\sqrt{\mathrm{n}}}\end{array}$ \\
\hline 3.00 & $1.294,1.595,1.566$ & 1.485 & 0.1660 & 11.1814 & $1.485 \pm 0.412$ \\
\hline 2.00 & $1.299,1.068,1.265$ & 1.210 & 0.1247 & 10.3015 & $1.210 \pm 0.309$ \\
\hline 1.00 & $0.700,0.675,0.694$ & 0.689 & 0.0130 & 1.8923 & $0.689 \pm 0.0324$ \\
\hline 0.50 & $0.204,0.317,0.321$ & 0.280 & 0.0664 & 23.6670 & $0.280 \pm 0.164$ \\
\hline 0.25 & $0.242,0.212,0.223$ & 0.223 & 0.0151 & 6.8057 & $0.223 \pm 0.037$ \\
\hline
\end{tabular}

\begin{tabular}{|c|c|c|c|c|c|c|}
\hline \multicolumn{7}{|c|}{$\begin{array}{c}\text { TABLE-6 } \\
\text { REPEATABILITY OF Fe(III) COMPLEX AT OPTIMUM PARAMETERS }\end{array}$} \\
\hline \multicolumn{2}{|c|}{$\begin{array}{l}\text { Concentration of } \\
\text { metal }\left(\mu \mathrm{g} \mathrm{mL} L^{-1}\right)\end{array}$} & $\begin{array}{c}\text { Absorbance } \\
\bar{y}_{\mathrm{i}}\end{array}$ & Mean $\bar{y}$ & $\begin{array}{c}\text { Standard } \\
\text { deviation } \\
\sigma_{n-1}\end{array}$ & $\begin{array}{l}\text { Repeatability } \\
\text { RSD }(\%)\end{array}$ & $\begin{array}{l}\text { Confidence interval of mean } \\
\qquad \overline{\mathrm{y}} \pm \mathrm{t}_{0.05 / 2} \frac{\sigma_{\mathrm{n}-1}}{\sqrt{\mathrm{n}}}\end{array}$ \\
\hline \multirow{2}{*}{$\mathrm{Fe}(\mathrm{III})$} & 0.5 & $0.252,0.355,0.295,0.332,0.300,0.313$ & 0.307833 & 0.035153 & 3.515347 & $0.307 \pm 0.0368$ \\
\hline & 2.0 & $0.396,0.401,0.411,0.429,0.399,0.399$ & 0.405833 & 0.012465 & 3.071363 & $0.405 \pm 0.0130$ \\
\hline
\end{tabular}

Calibration curve of Fe(III) by FAAS: A series of standard iron(III) solutions ranging from $0-5 \mu \mathrm{g} \mathrm{mL}^{-1}$ were used at $\lambda_{\max }$ 248.3 in order to determine the calibration curve for $\mathrm{Fe}(\mathrm{III})$ in FAAS technique. Fig. 13 shows the range of concentration of Fe (III), results of absorbance for linear regression analysis using FAAS.

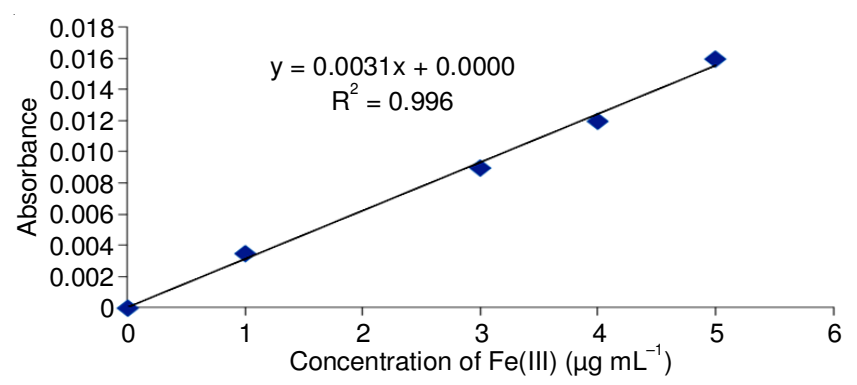

Fig. 13. Calibration graph for $\mathrm{Fe}(\mathrm{III})$ by FAAS
Analytical applications: After the digestion of urine sample pre-concentrated by cloud point extraction and determine the Fe(III) concentration in urine of 44 samples of occupational workers by two methods UV-visible-CPE and FAAS$\mathrm{CPE}$ at the optimum conditions. The results are presented in Tables 7 and 8.

Statistical treatment of results: By applying a Grubbstest to outlier of the sample concentrations after estimating by UV-visible spectrophotometry, FAAS techniques, the results were excluded as shown in Table-9. This test was applied to 44 samples as shown in Table-10. The significance tests described so far are used for comparing means, and hence for detecting systematic errors. The F-test was used to compare the variances between the concentration of iron by two methods UV-Vis-CPE and FAAS-CPE to appear have significant or not between them [30]. Table-11 shows the results of applied Ftest. And the comparison of a sample mean with true mean

TABLE-7

RESULT OF Fe(III) CONCENTRATION IN URINE SAMPLE BY USING UV-VISIBLE SPECTROPHOTOMETER

\begin{tabular}{|c|c|c|c|c|c|c|}
\hline ID & Gender & Age & $\begin{array}{c}\text { Type of } \\
\text { occupational worker }\end{array}$ & $\begin{array}{l}\text { Duration of } \\
\text { work (year) }\end{array}$ & $\begin{array}{l}\text { Absorbance of } \mathrm{Fe}(\mathrm{III}) \\
\text { by UV-visible } \\
\text { spectrophotometer }\end{array}$ & $\begin{array}{l}\text { Concentration of } \mathrm{Fe}(\mathrm{III}) \\
\mu \mathrm{g} \mathrm{mL} \mathrm{mL}^{-1} \text { in urine samples } \\
\text { by } \mathrm{UV}-\mathrm{Vis}-\mathrm{CPE} \text { method }\end{array}$ \\
\hline H001 & Male & 55 & Oil refineries & 35 & 0.980 & 0.065427 \\
\hline H002 & Male & 37 & Oil refineries & 12 & 0.110 & -0.001296 \\
\hline $\mathrm{H} 003$ & Male & 28 & Oil refineries & 7 & 1.019 & 0.068418 \\
\hline H004 & Male & 26 & Welding & 2 & 1.179 & 0.080689 \\
\hline H005 & Male & 27 & Welding & 6 & 1.233 & 0.084830 \\
\hline H006 & Male & 50 & Welding & 25 & 1.261 & 0.086978 \\
\hline $\mathrm{H} 007$ & Male & 23 & Plumbing & 8 & & \\
\hline $\mathrm{H} 008$ & Male & 22 & Plumbing & 7 & 1.439 & 0.100629 \\
\hline H009 & Male & 60 & Plumbing & 20 & 0.715 & 0.045103 \\
\hline $\mathrm{H} 010$ & Male & 49 & Plumbing & 35 & & \\
\hline H011 & Male & 28 & Plumbing & 2 & 0.981 & 0.065504 \\
\hline H012 & Male & 29 & Welding & 15 & 1.012 & 0.067881 \\
\hline H013 & Male & 53 & Dyeing & 10 & 1.109 & 0.075320 \\
\hline H014 & Male & 45 & Welding & 20 & 0.813 & 0.052619 \\
\hline H015 & Male & 32 & Dyeing & 9 & & \\
\hline H016 & Male & 25 & Dyeing & 11 & 2.101 & 0.151400 \\
\hline H017 & Male & 27 & Oil refineries & 10 & 1.009 & 0.067651 \\
\hline H018 & Male & 26 & Dyeing & 2 & 1.200 & 0.082299 \\
\hline H019 & Male & 35 & Dyeing & 20 & 1.393 & 0.097101 \\
\hline $\mathrm{H} 020$ & Male & 45 & Oil refineries & 4 & 1.112 & 0.075550 \\
\hline
\end{tabular}




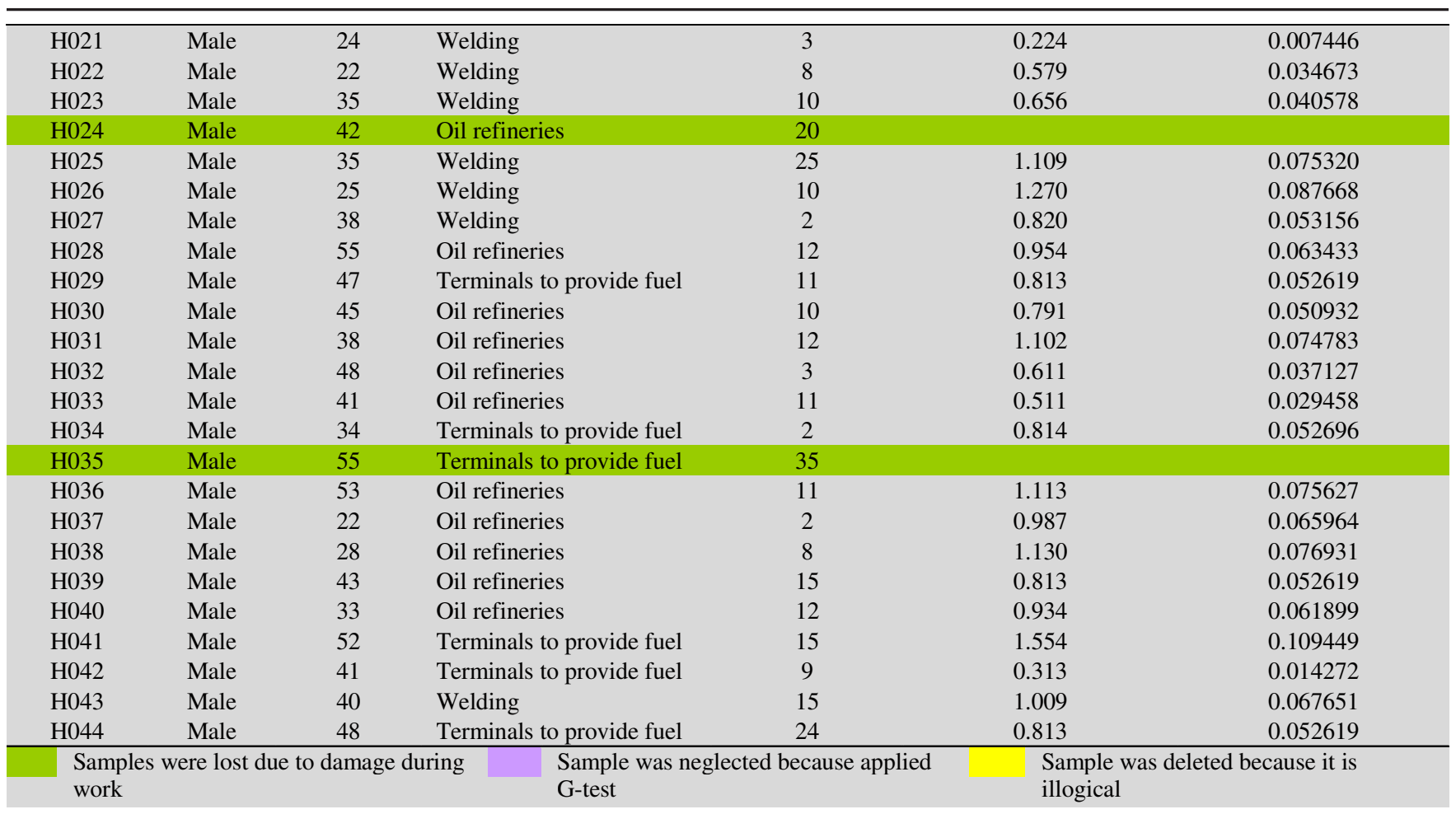

\section{RESULT OF Fe(III) CONCENTRATION IN URINE SAMPLE BY USING FAAS}

\begin{tabular}{|c|c|c|c|c|c|c|}
\hline ID & Gender & Age & $\begin{array}{c}\text { Type of } \\
\text { occupational worker }\end{array}$ & $\begin{array}{l}\text { Duration of } \\
\text { work (year) }\end{array}$ & $\begin{array}{c}\text { Absorbance of Fe(III) } \\
\text { by FAAS }\end{array}$ & $\begin{array}{c}\text { Concentration of } \mathrm{Fe}(\mathrm{III}) \\
\mu \mathrm{g} \mathrm{mL} \mathrm{mL}^{-1} \text { in urine samples } \\
\text { by FAAS-CPE }\end{array}$ \\
\hline $\mathrm{H} 001$ & Male & 55 & Oil refineries & 35 & 0.004 & 0.052083 \\
\hline H002 & Male & 37 & Oil refineries & 12 & 0.002 & 0.104166 \\
\hline $\mathrm{H} 003$ & Male & 28 & Oil refineries & 7 & 0.009 & 0.023148 \\
\hline H004 & Male & 26 & Welding & 2 & 0.007 & 0.029761 \\
\hline H005 & Male & 27 & Welding & 6 & 0.003 & 0.069444 \\
\hline H006 & Male & 50 & Welding & 25 & 0.003 & 0.069444 \\
\hline H007 & Male & 23 & Plumbing & 8 & & \\
\hline H008 & Male & 22 & Plumbing & 7 & 0.008 & 0.026041 \\
\hline H009 & Male & 60 & Plumbing & 20 & 0.005 & 0.041666 \\
\hline H010 & Male & 49 & Plumbing & 35 & & \\
\hline H011 & Male & 28 & Plumbing & 2 & 0.005 & 0.041666 \\
\hline H012 & Male & 29 & Welding & 15 & 0.004 & 0.052083 \\
\hline H013 & Male & 53 & Dyeing & 10 & 0.001 & 0.208333 \\
\hline H014 & Male & 45 & Welding & 20 & 0.006 & 0.034722 \\
\hline H015 & Male & 32 & Dyeing & 9 & & \\
\hline H016 & Male & 25 & Dyeing & 11 & 0.004 & 0.052083 \\
\hline H017 & Male & 27 & Oil refineries & 10 & 0.004 & 0.052083 \\
\hline H018 & Male & 26 & Dyeing & 2 & 0.005 & 0.041666 \\
\hline H019 & Male & 35 & Dyeing & 20 & 0.002 & 0.104166 \\
\hline H020 & Male & 45 & Oil refineries & 4 & 0.003 & 0.069444 \\
\hline H021 & Male & 24 & Welding & 3 & 0.004 & 0.052083 \\
\hline H022 & Male & 22 & Welding & 8 & 0.005 & 0.041666 \\
\hline $\mathrm{H} 023$ & Male & 35 & Welding & 10 & 0.002 & 0.104166 \\
\hline $\mathrm{H} 024$ & Male & 42 & Oil refineries & 20 & & \\
\hline H025 & Male & 35 & Welding & 25 & 0.010 & 0.020833 \\
\hline H026 & Male & 25 & Welding & 10 & 0.005 & 0.041666 \\
\hline H027 & Male & 38 & Welding & 2 & 0.005 & 0.041666 \\
\hline H028 & Male & 55 & Oil refineries & 12 & 0.005 & 0.041666 \\
\hline H029 & Male & 47 & Terminals to provide fuel & 11 & 0.004 & 0.052083 \\
\hline $\mathrm{H} 030$ & Male & 45 & Oil refineries & 10 & 0.006 & 0.034722 \\
\hline $\mathrm{H} 031$ & Male & 38 & Oil refineries & 12 & 0.009 & 0.023148 \\
\hline H032 & Male & 48 & Oil refineries & 3 & 0.004 & 0.052083 \\
\hline $\mathrm{H} 033$ & Male & 41 & Oil refineries & 11 & 0.007 & 0.029761 \\
\hline H034 & Male & 34 & Terminals to provide fuel & 2 & 0.007 & 0.029761 \\
\hline H035 & Male & 55 & Terminals to provide fuel & 35 & & \\
\hline
\end{tabular}




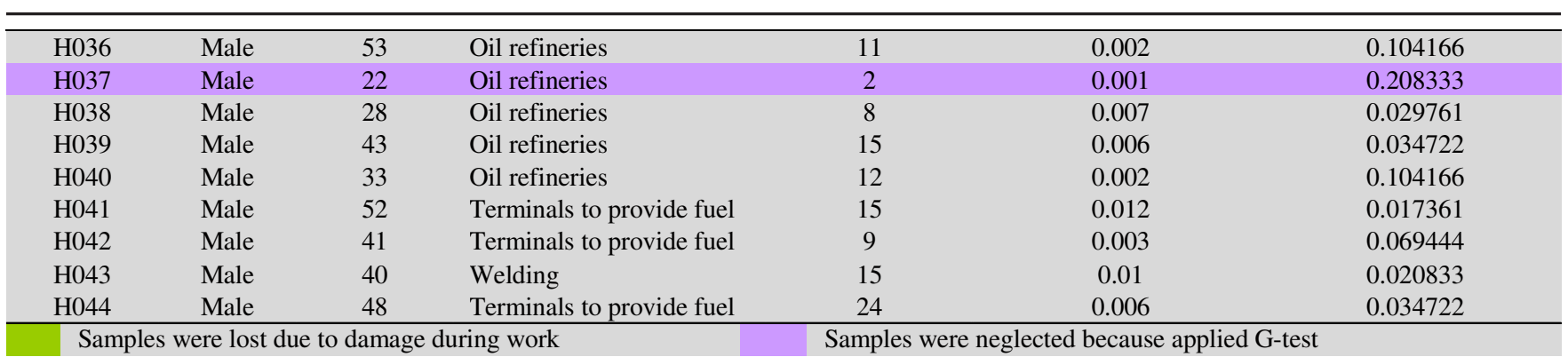

\begin{tabular}{|c|c|c|c|c|c|c|}
\hline \multirow{3}{*}{\multicolumn{2}{|c|}{ No. of sample }} & \multicolumn{3}{|c|}{$\begin{array}{c}\text { TABLE-9 } \\
\text { RESULTS OF GRUBBS-TEST APPLIED ON Fe(III) }\end{array}$} & & \\
\hline & & \multicolumn{2}{|c|}{ Readings excluded } & \multirow{2}{*}{$\begin{array}{c}\text { Factor of } \\
\text { concentration cf }\end{array}$} & \multicolumn{2}{|c|}{ Mean of concentration } \\
\hline & & UV-Visible & FAAS & & UV-Visible & FAAS \\
\hline $\mathrm{Fe}(\mathrm{III})$ & 44 & 7 & 7 & 22.5 & $0.007-0.151$ & $0.017-0.208$ \\
\hline
\end{tabular}

\begin{tabular}{|c|c|c|c|c|c|}
\hline \multicolumn{6}{|c|}{$\begin{array}{c}\text { TABLE-10 } \\
\text { CLASSIFICATION OF TYPES OF SAMPLES AND STATISTICAL RESULTS OF } \\
\text { Fe(III) TO THEM ACCORDING TO DIFFERENT TECHNIQUES }\end{array}$} \\
\hline $\begin{array}{l}\text { Type of } \\
\text { occupational } \\
\text { worker }\end{array}$ & Type of measurement & $\begin{array}{l}\text { No. of } \\
\text { sample }\end{array}$ & $\begin{array}{l}\text { Mean of conc. } \bar{y} \\
\quad\left(\mu \mathrm{g} \mathrm{mL^{-1 } )}\right.\end{array}$ & $\begin{array}{l}\text { Standard } \\
\text { deviation } \\
\sigma_{\mathrm{n}-1}\end{array}$ & $\begin{array}{l}\text { Confidence interval of the mean } \\
\qquad \overline{\mathrm{y}} \pm \mathrm{t}_{0.05 / 2} \frac{\sigma_{\mathrm{n}-1}}{\sqrt{\mathrm{n}}}\end{array}$ \\
\hline \multirow{2}{*}{ Oil refineries } & UV-Vis-CPE & 14 & 0.0636 & 0.0192 & $0.0636 \pm 0.0111$ \\
\hline & AAS-CPE & 14 & 0.0539 & 0.0300 & $0.0539 \pm 0.0173$ \\
\hline \multirow{2}{*}{ Welding } & UV-Vis-CPE & 12 & 0.0612 & 0.0246 & $0.0612 \pm 0.0156$ \\
\hline & AAS-CPE & 12 & 0.0481 & 0.0237 & $0.0481 \pm 0.0150$ \\
\hline \multirow{2}{*}{ Plumbing } & UV-Vis-CPE & 3 & 0.0704 & 0.0281 & $0.0704 \pm 0.0695$ \\
\hline & AAS-CPE & 3 & 0.0364 & 0.0090 & $0.0364 \pm 0.022$ \\
\hline \multirow{2}{*}{$\begin{array}{l}\text { Terminals to } \\
\text { provide fuel }\end{array}$} & UV-Vis-CPE & 5 & 0.0522 & 0.0236 & $0.0522 \pm 0.0292$ \\
\hline & AAS-CPE & 5 & 0.0406 & 0.0203 & $0.0406 \pm 0.0252$ \\
\hline \multirow{2}{*}{ Dyeing } & UV-Vis-CPE & 3 & 0.0849 & 0.0111 & $0.0849 \pm 0.0276$ \\
\hline & AAS-CPE & 3 & 0.0659 & 0.0334 & $0.0659 \pm 0.0829$ \\
\hline \multirow{2}{*}{ Total } & UV-Vis-CPE & 37 & 0.06359 & 0.0219 & $0.0635 \pm 0.0073$ \\
\hline & AAS-CPE & 37 & 0.05127 & 0.0261 & $0.0512 \pm 0.0087$ \\
\hline
\end{tabular}

TABLE-11

APPLICATION F-TEST ON THE Fe(III) SAMPLES

\begin{tabular}{|c|c|c|c|c|c|c|c|c|}
\hline $\begin{array}{c}\text { Type of } \\
\text { occupational } \\
\text { worker }\end{array}$ & $\begin{array}{c}\text { Type of } \\
\text { measurement }\end{array}$ & d.f $=n-1$ & $\begin{array}{c}\text { Standard } \\
\text { deviation } \\
\sigma_{n-1}\end{array}$ & Variance $\sigma^{2}$ & $\begin{array}{l}\text { F-calculate } \\
\qquad F=\frac{\sigma^{2}}{\sigma^{2}}\end{array}$ & $\begin{array}{l}\text { F-critical } \\
\text { value }\end{array}$ & P-value & Type of significant \\
\hline Oil refineries & $\begin{array}{l}\text { UV-Vis-CPE } \\
\text { AAS-CPE }\end{array}$ & $\begin{array}{l}13 \\
13\end{array}$ & $\begin{array}{l}0.0192 \\
0.0274\end{array}$ & $\begin{array}{l}0.000386 \\
0.000754\end{array}$ & 1.9736 & 2.69 & 0.13007 & Non-significant \\
\hline Welding & $\begin{array}{l}\text { UV-Vis-CPE } \\
\text { AAS-CPE }\end{array}$ & $\begin{array}{l}11 \\
11 \\
\end{array}$ & $\begin{array}{l}0.0246 \\
0.0237 \\
\end{array}$ & $\begin{array}{l}0.000605 \\
0.000562 \\
\end{array}$ & 1.0714 & 2.80 & 0.45633 & Non-significant \\
\hline Plumbing & $\begin{array}{l}\text { UV-Vis-CPE } \\
\text { AAS-CPE }\end{array}$ & $\begin{array}{l}2 \\
2\end{array}$ & $\begin{array}{l}0.0281 \\
0.0090\end{array}$ & $\begin{array}{c}0.00079 \\
0.000081\end{array}$ & 9.6296 & 19.00 & 0.0941 & Non-significant \\
\hline $\begin{array}{l}\text { Terminals to } \\
\text { provide fuel }\end{array}$ & $\begin{array}{l}\text { UV-Vis-CPE } \\
\text { AAS-CPE }\end{array}$ & $\begin{array}{l}4 \\
4 \\
\end{array}$ & $\begin{array}{l}0.0236 \\
0.0203 \\
\end{array}$ & $\begin{array}{l}0.000557 \\
0.000412 \\
\end{array}$ & 1.3414 & 6.39 & 0.3917 & Non-significant \\
\hline Dyeing & $\begin{array}{l}\text { UV-Vis-CPE } \\
\text { AAS-CPE }\end{array}$ & $\begin{array}{l}1 \\
1 \\
\end{array}$ & $\begin{array}{l}0.0104 \\
0.0441 \\
\end{array}$ & $\begin{array}{c}0.000109 \\
0.00195 \\
\end{array}$ & 17.889 & 161.45 & 0.14815 & Non-significant \\
\hline Total & $\begin{array}{l}\text { UV-Vis-CPE } \\
\text { AAS-CPE }\end{array}$ & $\begin{array}{l}34 \\
34\end{array}$ & $\begin{array}{l}0.0223 \\
0.0244\end{array}$ & $\begin{array}{c}0.00049 \\
0.000681\end{array}$ & 44.76 & 1.79 & $<0.00001$ & Significant \\
\hline
\end{tabular}

must be based on Student's t test to compare the mean of iron concentration by two methods UV-visible-CPE and FAASCPE [31]. Table-12 shows the result of t-Test.

\section{Conclusion}

A sensitive, selective and environmentally friendly spectrometric method of determination of low concentrations of Fe(III), using benzidine as a complexing agent and cloud point extraction is developed. The proposed method was succcessfully applied for the determination of urine samples of occupational workers.

\section{REFERENCES}

1. Y.A. Zolotov and N.M. Kuz'min, Preconcentration of Trace Elements, Elsevier Science Publishers B.V., Amsterdam (1990).

2. C.C. Nascentes and M.A.Z. Arruda, Talanta, 61, 759 (2003); https://doi.org/10.1016/S0039-9140(03)00367-9. 


\begin{tabular}{|c|c|c|c|c|c|c|c|c|}
\hline \multicolumn{9}{|c|}{$\begin{array}{c}\text { TABLE-12 } \\
\text { STUDENT t-TEST OF Fe(III) RESULTS OF UV-Vis-CPE AND AAS-CPE }\end{array}$} \\
\hline $\begin{array}{c}\text { Type of } \\
\text { occupational } \\
\text { worker }\end{array}$ & $\begin{array}{l}\text { Type of } \\
\text { measurement }\end{array}$ & d.f $=$ n-1 & $\begin{array}{l}\text { Mean of } \\
\text { conc. } \bar{y} \\
\left(\mu g \mathrm{~mL}^{-1}\right)\end{array}$ & $\begin{array}{c}\text { Standard } \\
\text { deviation } \\
\sigma_{\mathrm{n}-1}\end{array}$ & $\begin{array}{l}\text { Confidence } \\
\text { interval of the } \\
\text { mean } \\
\overline{\mathrm{y}} \pm \mathrm{t}_{0.05 / 2} \frac{\sigma_{\mathrm{n}-1}}{\sqrt{\mathrm{n}}}\end{array}$ & $\begin{array}{l}\mathrm{t} \text {-calculated } \\
\mathrm{t}=\overline{\mathrm{y}}-\mu \frac{\sqrt{\mathrm{n}}}{\sigma_{\mathrm{n}-1}}\end{array}$ & P-value & $\begin{array}{l}\text { Type of } \\
\text { significant }\end{array}$ \\
\hline \multirow{2}{*}{ Oil refineries } & UV-Vis-CPE & 13 & 0.0636 & 0.0192 & $0.0636 \pm 0.0111$ & 11.437 & $<0.00001$ & Non-significant \\
\hline & AAS-CPE & 13 & 0.05007 & 0.02747 & $0.0500 \pm 0.0173$ & 5.9283 & 0.00069 & Non-significant \\
\hline \multirow{2}{*}{ Welding } & UV-Vis-CPE & 11 & 0.0612 & 0.0246 & $0.0612 \pm 0.0156$ & 7.9277 & $<0.00001$ & Non-significant \\
\hline & AAS-CPE & 11 & 0.0481 & 0.0237 & $0.0481 \pm 0.0150$ & 6.3141 & 0.000058 & Non-significant \\
\hline \multirow{2}{*}{ Plumbing } & UV-Vis-CPE & 2 & 0.0704 & 0.0281 & $0.0704 \pm 0.0695$ & 4.0400 & 0.05615 & Significant \\
\hline & AAS-CPE & 2 & 0.0364 & 0.0090 & $0.0364 \pm 0.022$ & 6.0485 & 0.026266 & Significant \\
\hline \multirow{2}{*}{$\begin{array}{l}\text { Terminals to } \\
\text { provide fuel }\end{array}$} & UV-Vis-CPE & 4 & 0.0522 & 0.0236 & $0.0522 \pm 0.0292$ & 4.4814 & 0.010978 & Non-significant \\
\hline & AAS-CPE & 4 & 0.0406 & 0.0203 & $0.0406 \pm 0.0252$ & 3.9322 & 0.017074 & Non-significant \\
\hline \multirow{2}{*}{ Dyeing } & UV-Vis-CPE & 2 & 0.0849 & 0.0111 & $0.0849 \pm 0.0276$ & 12.4828 & 0.006357 & Non-significant \\
\hline & AAS-CPE & 2 & 0.0659 & 0.0334 & $0.0659 \pm 0.0829$ & 3.1632 & 0.087094 & Significant \\
\hline \multirow{2}{*}{ Total } & UV-Vis-CPE & 35 & 0.06359 & 0.0219 & $0.0635 \pm 0.0073$ & 16.2742 & $<0.00001$ & Non-significant \\
\hline & AAS-CPE & 35 & 0.05127 & 0.0261 & $0.0512 \pm 0.0087$ & 10.764 & $<0.00001$ & Non-significant \\
\hline
\end{tabular}

$\mathrm{n}=39(2.024)$.

3. S. Ferreira, J. Deandrade, M. Korn, M. Pereira, V. Lemos, W. Santos, F. Rodrigues, A. Souza, H. Ferreira and E. Dasilva, J. Hazard. Mater, 145, 358 (2007);

https://doi.org/10.1016/j.jhazmat.2007.03.077.

4. Z. Alfassi and C.M. Wai, Preconcentration Techniques For Trace Elements, CRC Press, pp. 480 (1991).

5. D.E. Leyden and W. Wegscheider, Anal. Chem., 53, 1059A (1981); https://doi.org/10.1021/ac00232a731.

6. L.A. Escaleira, R.E. Santelli, E.P. Oliveira, M.F.B. Carvalho and M.A. Bezerra, Int. J. Environ. Anal. Chem., 89, 515 (2009); https://doi.org/10.1080/03067310802592763.

7. F. Quina and W.L. Hinze, Ind. Eng. Chem. Res., 38, 4150 (1999); https://doi.org/10.1021/ie980389n.

8. E. Pramauro and A. Prevot, Pure Appl. Chem, 67, 551 (1995); https://doi.org/10.1351/pac199567040551.

9. F. Shemirani, S.D. Abkenar, A.A. Mirroshandel, M.S. Niasari and R.R. Kozania, Anal. Sci., 19, 1453 (2003); https://doi.org/10.2116/analsci.19.1453.

10. A.F. Khudhair, S.I. Saeed, S.K. Abbas and H.M. Mohsin, Asian J. Chem., 29, 1065 (2017); https://doi.org/10.14233/ajchem.2017.20410.

11. M. Valko, H. Morris and M.T.D. Cronin, Curr. Med. Chem., 12, 1161 (2005);

https://doi.org/10.2174/0929867053764635.

12. C.A. Sahin, I. Tokgöz and S. Bektas, J. Hazard. Mater., 181, 359 (2010); https://doi.org/10.1016/j.jhazmat.2010.05.018.

13. P.T. Lieu, M. Heiskala, P.A. Peterson and Y. Yang, Mol. Aspects Med., 22, 1 (2001); https://doi.org/10.1016/S0098-2997(00)00006-6

14. R.L. Nelson, Free Radic. Biol. Med., 12, 161 (1992); https://doi.org/10.1016/0891-5849(92)90010-E

15. F. Shakerian, S. Dadfarnia and A.M.H. Shabani, J. Iran. Chem. Soc., 6, 594 (2009); https://doi.org/10.1007/BF03246539.

16. M. Ghaedi, A. Shokrollahi, R. Mehrnoosh, O. Hossaini and M. Soylak, Cent. Eur. J. Chem., 6, 488 (2008); https://doi.org/10.2478/s11532-008-0049-9.
17. Z.A.A. Khammas and R.A. Rashid, Int. J. Chem. Sci., 14, 955 (2016).

18. H. Filik and D. Giray, Food Chem., 130, 209 (2012); https://doi.org/10.1016/j.foodchem.2011.07.008.

19. A. Ohashi, H. Ito, C. Kanai, H. Imura and K. Ohashi, Talanta, 65, 525 (2005); https://doi.org/10.1016/j.talanta.2004.07.018.

20. G. Peng, Q. He, G. Zhou, Y. Li, X. Su, M. Liu and L. Fan, Anal. Methods, 10, 1039 (2010).

21. C. Ortega, S. Cerutti, R.A. Olsina, L.D. Martínez and M.F. Silva, J. Pharm. Biomed. Chem., 36, 721 (2004); https://doi.org/10.1016/j.jpba.2004.08.027.

22. https://en.wikipedia.org/wiki/Urine

23. C. Rosea, A. Parkera, B. Jeffersona and E. Cartmella, Sunny Health Science Center, 15, 18 (2015).

24. A. Kanzler, Overview of Urine Diversion Components such as Waterless Urinals, Urine Diversion Toilets, Urine Storage and Reuse Systems, Technology Review, Urine Diversion Components, Deutsche Gesellschaft für Technische Zusammenarbeit GmbH (GTZ) Sustainable SanitationEcosan Program Postfach 5180, 65726 Eschborn, Germany (2009).

25. I. Rodushkin and F. Odman, J. Trace Elem. Med. Biol., 14, 241 (2001); https://doi.org/10.1016/S0946-672X(01)80010-9.

26. R. Brodzka, M. Trzcinka-Ochocka and B. Janasik, Int. J. Occup. Med. Environ. Health, 26, 302 (2013); https://doi.org/10.2478/s13382-013-0106-2.

27. P. Davletbaeva, M. Falkova, E. Safonova, L. Moskvin and A. Bulatov, Anal. Chim. Acta, 911, 69 (2016); https://doi.org/10.1016/j.aca.2015.12.045.

28. A. Afkhami, T. Madrakian and H. Siampour, J. Braz. Chem. Soc., 17, 797 (2006); https://doi.org/10.1590/S0103-50532006000400024.

29. A.S. Amin, Spectrosc. Lett., 44, 424 (2011); https://doi.org/10.1080/00387010.2011.574308.

30. D. Harvey, Chromatographic and Electrophoretic Methods, Analytical Chemistry, Chap. 12, pp. 543-621 (2000).

31. M. Otto, Statistics and Computer Application in Analytical Chemistry, British Library Cataloguing, edn 3 (2016). 